\title{
Monokine-Induced Gene Expression of a Human Endothelial Cell-Derived Neutrophil Chemotactic Factor
}

\author{
R.M. Strieter ${ }^{*}$, S.L. Kunkel, H.J. Showell ${ }^{* *}$, and R.M. Marks \\ * Division of Pulmonary and Critical Care Medicine, Department of Internal Medicine, \\ Department of Pathology, The University of Michigan Medical School, Ann Arbor, \\ Michigan \\ *** Department of Immunology, Pfizer Central Research, Groton, Connecticut
}

Received October 7, 1988

Monokines have been increasingly recognized as communication signals that interact with both immune and non-immune cells during inflammation. Specifically, interleukin-1alpha (IL-1alpha), interleukin-1beta (IL-1beta) and tumor necrosis factoralpha (TNF-alpha) possess potent effector activities on various cell types. We present novel data demonstrating that human endothelial cells are a major source of a neutrophil chemotactic factor (NCF) synthesized upon stimulation with either IL1alpha, IL-1beta, or TNF-alpha; but not with interleukin-6 (IL-6). Northern blot analysis demonstrated that $20 \mathrm{ng} / \mathrm{ml}$ of either IL-1 or TNF-alpha could induce endothelial cells to express significant levels of NCF mRNA, while IL-6 was not active in this system. These data demonstrate that monokines play an important role in mediating acute inflammation via induction of an endothelial cell-derived NCF.

- 1988 Academic Press, Inc.

The evolution of an inflammatory response is dependent upon cell-to-cell communication via protein signals that bind to specific receptors and result in target cell activation. These complex events are mediated by products of both immune cells found in tissue and the peripheral circulation, as well as endothelial cells that line the vasculature. A number of studies have demonstrated that endothelial cells are susceptible to cytokine-induced stimulation that results in altering endothelial cell function leading to the active participation of this cell in inflammation (1-5). Specifically, both IL-1 and TNF-alpha can induce adherence proteins on the surface of endothelial cells that bind polymorphonuclear leukocytes (6-7). The expression of these surface proteins are potentially an important mechanism for trapping circulating

Abbreviations used in this manuscript: IL-1, interleukin-1, TNF, tumor necrosis factor alpha; IL-6, interleukin-6, NCF, neutrophil chemotactic factor. 
neutrophils in a localized area of tissue injury, yet this process does not account for the selective influx of neutrophils into an area of local inflammation.

In this paper, we present novel data demonstrating that monokine-activated endothelial cells may further contribute to acute inflammation by the production of a specific neutrophil chemotactic factor (NCF). Either IL-1 alpha, IL-1 beta, or TNFalpha-treated endothelial cells induced a time- and dose-dependent increase in NCF mRNA expression and the production of chemotactic activity. The induction of NCF mRNA and the secretion of biologically-active protein possessed a degree of cytokine selectivity, as interleukin-6-treated human endothelial cells was not effective in this system. These studies demonstrate that either IL-1 or TNF can induce NCF gene expression by endothelial cells and this factor may play a major role in the early influx of neutrophils from the circulation.

\section{Materials and Methods}

Endothelial Cell Populations: Human endothelial cells were isolated from umbilical veins according to previously published procedures (8). The recovered endothelial cells were cultured in medium 199 supplemented with $100 \mathrm{ng} / \mathrm{ml}$ endothelial cell growth supplement, $25 \%$ fetal bovine serum, and $100 \mathrm{ng} / \mathrm{ml}$ bovine lung heparin. All cells in these studies were used prior to their fifth passage in culture. Twenty-four hours before stimulation, the endothelial cells were washed and new media, minus growth factors, were added.

Reagents: Human recombinant IL-1alpha and IL-1beta with specific activities of 20 $\mathrm{U} / \mathrm{ng}$ and $30 \mathrm{U} / \mathrm{ng}$, respectively, were the generous gifts of the Upjohn Company. Human recombinant TNF (20 U/ng, specific activity) was a gift of the Cetus Corporation. Human recombinant IL-6 $(20 \mathrm{U} / \mathrm{ul})$ was purchased from Genzyme Inc.

Northern Blot Analysis: Total endothelial cell RNA was extracted using a modification of the methods of Jonas et al. (9). and Chirgwin et al. (10). The adherent endothelial cells were solubilized in a solution of $25 \mathrm{mM}$ Tris, pH 8.0 containing $4.2 \mathrm{M}$ guanidine isothiocyanate, $0.5 \%$ Sarkosyl and $0.1 \mathrm{M}$ beta-mercaptoethanol. After homogenization, an equal volume of $100 \mathrm{mM}$ Tris, $\mathrm{pH} 8.0$ containing $1.0 \%$ SDS and 10 mM EDTA was added and the RNA extracted with chloroform-phenol. The alcohol precipitated RNA was separated by formaldehyde/1\% agarose gels and transblotted to nitrocellulose. The baked blots were prehybridized and then hybridized with a $32 \mathrm{P}-5$ 'end labeled 30 mer oligonucleotide probe. The probe was complementary to nucleotides 262-291 of a published cDNA sequence for human monocyte-derived NCF (11). The sequence of the probe was 5'-GTT-GGC-GCA-GTG-TGG-TCC-ACT-CTCATT-CAC-3'. Blots were stringency washed and autoradiographs were quantitated by laser densitometry. Equivalent amounts of total RNA load per gel lane were assessed by monitoring 28 and $18 \mathrm{~S}$ rRNA.

Neutrophil Chemotactic Factor Assay: Human neutrophils were prepared from peripheral blood by Ficoll-Hypaque density gradient centrifugation, followed by sedimentation in $5 \%$ Dextran/0.9\% saline (Sigma Chemical Co., St. Louis, MO). Neutrophils were isolated from erythrocytes by hypotonic lysis then resuspended in Hanks balanced salt solution (HBSS) with calcium/magnesium (Gibco, Grand Island, $\mathrm{NY}$ ) at $2 \times 10^{6}$ cells $/ \mathrm{ml}$ with greater than $95 \%$ viability by trypan blue exclusion. Chemotaxis was performed using the method of Harvath et al (12). Briefly, 20 ul of diluted supernatant specimen, $10^{-7} \mathrm{M}$ formyl methionylleucylphenylalanine (FMLP, Sigma Chemical Co., St. Louis, MO) or HBSS alone were placed in duplicate bottom 
wells of a 48-well microchemotaxis chamber (Neuro probe, Cabin John, MD). A 3 micron pore-size polycarbonate filter (polyvinylpyrolidone-free, Nucleopore Corp.) was placed in the assembly and $50 \mathrm{ul}$ of neutrophil suspension placed in each of the top wells. After incubating at $37^{\circ} \mathrm{C}$ in humidified $95 \%$ air $/ 5 \% \mathrm{CO}_{2}$ for $0.5 \mathrm{hrs}$, the filters were removed, fixed in methanol, and stained with Diff-Quik (American Scientific Products, McGaw Park, IL). Neutrophils that had migrated through to the bottom of the filter were counted in 10 high power fields. Chemotactic activity was assessed as percent of the FMLP positive control.

\section{Results}

Monokine-Induced Expression of NCF mRNA: Initially, human endothelial cells grown to confluency were stimulated for 16 hours with 200 Units/ml of either IL-1 alpha, IL-1 beta, TNF-alpha or IL-6 and total RNA was recovered. Northern blot analysis demonstrated a significant expression of NCF mRNA from either IL-1 alpha, IL-1 beta, or TNF-alpha-treated endothelial cells (Figure 1). On the contrary, IL-6stimulated endothelial cells did not induce NCF mRNA expression. The insert in Figure 1 shows the Northern blot (top) and the corresponding 28 and $18 \mathrm{~S}$ ribosomal RNA (bottom). Characterization of the Northern blot demonstrated an NCF mRNA species of $1.8 \mathrm{~Kb}$. The cells that had media alone demonstrated only a trace of NCF $0 \mathrm{~h}-\mathrm{IL}-1$, Con $\alpha$ S TNF IL -6
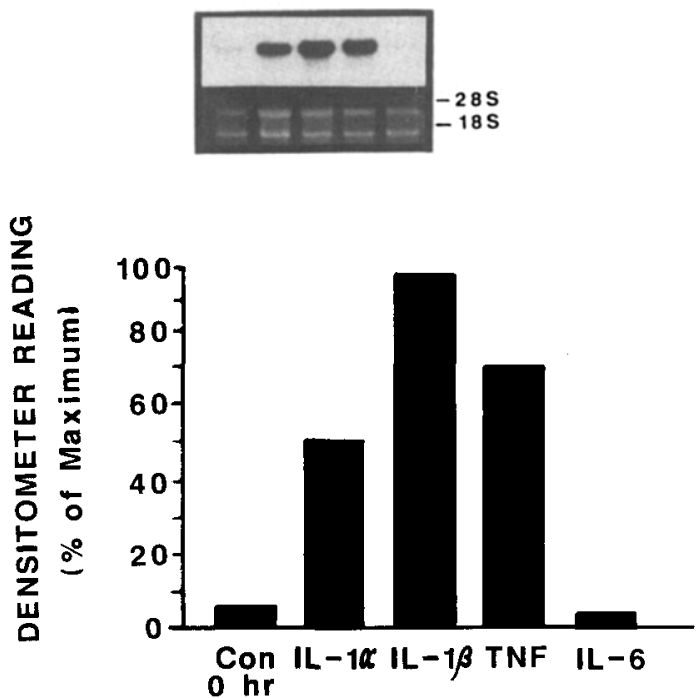

Figure 1. Induction of endothelial cell derived NCF mRNA by IL-1 and TNFalpha, but not IL-6. Human endothelial cells were treated with 200 Units/ml of each cytokine and total RNA was extracted 16 hours post-challenge. The insert shows the Northern blot (top) of the NCF mRNA compared to the 28 and $18 \mathrm{~S}$ ribosomal RNA (bottom). The bar graph represents the laser densitometry of the individual autoradiographs. 
mRNA during the study period. As shown by the laser densitometry data in Figure 1, IL-1 beta and TNF-alpha stimulated endothelial cells possessed nearly equal potency in inducing the expression of NCF mRNA, while IL-1 alpha appeared less effective.

Production of Biologically-Active NCF by IL-1 and TNF-Treated Endothelial Cells: In order to correlate the production of chemotactic activity with the expression of NCF mRNA, supernatant from control, IL-1 alpha, IL-1 beta, or IL-6-treated endothelial cells were assessed for the production of chemotactic activity. As shown in Figure 2, IL-1 alpha, IL-1 beta, and TNF-alpha-induced the synthesis of significant levels of NCF activity by 16 hours, while the level of IL-6-induced NCF was identical to the media control. An approximate 12-fold increase above controls in the levels of biologicallyactive NCF was observed when endothelial cells were challenged with $20 \mathrm{ng} / \mathrm{ml}$ of either of the stimulating monokines.

Kinetic Analysis of Monokine-Induced NCF Bioactivity: In order to assess the timedependent increase in the production of NCF, endothelial cells were treated with 20 $\mathrm{ng} / \mathrm{ml}$ of either IL-1 alpha or IL-1 beta and chemotactic activity determined 2, 4, 8, and 24 hours later. As shown in Figure 3, either IL-1alpha or IL-1beta-induced the synthesis of low levels of NCF by the 4 hour point, but by 8 hours significant levels of

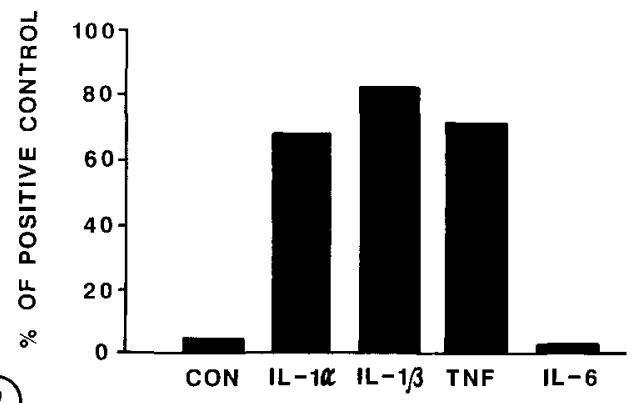

$\operatorname{CON} \quad \mathrm{IL}-1 \alpha \quad \mathrm{IL}-1 \beta$ TNF IL-6
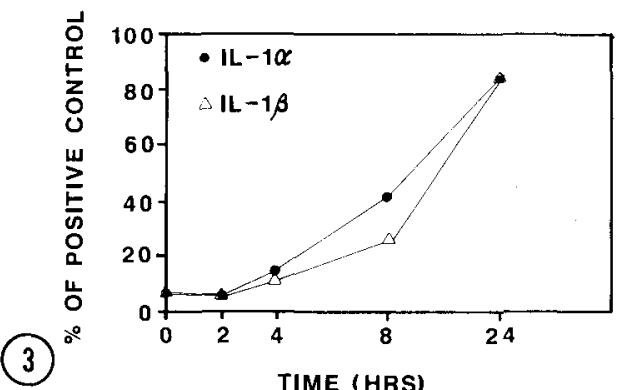

TIME (HRS)

Figure 2. Production of neutrophil chemotactic activity by either IL-1 alpha, IL-1 beta, or TNF-alpha treated human endothelial cells. The endothelial cells were exposed to each cytokine (200 Units/ml) for 16 hours and the supernatant was assessed for neutrophil chemotactic activity. Both IL-1 and TNF-alpha effectively induced the synthesis of de novo chemotactic activity, while IL-6 was ineffective in this system.

Figure 3. Time-dependent production of neutrophil chemotactic activity by monokine treated endothelial cells. Both IL-1 alpha and IL-1 beta (200 Units/ml) treated endothelial cells demonstrated a time-dependent increase in the production of NCF. Although the secretion of endothelial cell NCF was initially low (0-4 hours), the production significantly increased at the 8 and 24 hour time points. TNF-alpha treated human endothelial cells exhibited a similar kinetic pattern of NCF expression. 
NCF could be assessed. At 8 hours post-IL-1 challenge, the endothelial cell supernatant contained a 4-5 fold increase in NCF activity above controls. Twenty-four hours after IL-1 stimulation, the endothelial cell-derived NCF activity was approximately 8-fold above controls. Endothelial cells treated with IL-6 did not increase the levels of NCF above control values, while TNF-alpha treatment demonstrated activity consistent with the IL-1 treated endothelial cells (data not shown).

\section{Discussion}

It is becoming increasingly apparent that endothelial cells are important participants in the initiation and maintenance of acute inflammation. The anatomical location of these cells places the endothelium in a pivotal position to provide a communication bridge between the inflammatory cells of the peripheral blood and the interstitium. Previous studies have demonstrated that endothelial cells are susceptible to stimulation/activation by cytokines derived from cither T-cells (6) or macrophages $(1,4)$. In the latter case, IL-1 and TNF have been identified as specific macrophagederived proteins that possess overlapping effector activities on endothelial cells. Both IL-1 and TNF can induce the production of endothelial cell-derived tissue factor $(5,13)$, arachidonate metabolites (14), platelet-derived growth factor (15) and neutrophil adherence proteins $(6,7)$.

In addition to influencing neutrophil function via the induction of specific adherence proteins, we now demonstrate that either IL-1alpha, IL-1beta, or TNF can stimulate endothelial cells to produce a potent neutrophil chemotatic factor. Thus, monokine/endothelial cell interactions cannot only induced the adherence of neutrophils in a defined area of inflammation, but also initiate the unidirectional movement of these cells into an inflamed area in a polarized fashion. Interestingly, the induction of cytokine-induced NCF production by endothelial cells demonstrated selectivity, as IL-6 was not effective in this system. In total, these studies show that monokines can stimulate the production of a neutrophil chemotactic factor from human endothelial cells that may have important consequences in acute, neutrophilmediated inflammation. 
Acknowledgements: This work is supported by NIH grants HL31237, HL31963, and HL35276. Dr. Kunkel is an Established Investigator of the American Heart Association and Dr. Marks is a traveling fellow of the National Health and Medical Research Council of Australia. The authors thank Dr. Glenn Andrews for the synthesis of the oligonucleotide and Mrs. Kathleen Atkins for secretarial support.

\section{References}

1. Le, J., and Vilcek, J. (1987) Lab. Invest. 56,234-248.

2. Pohlman, T.H., Stanness, K.A., Beatty, P.G., Ochs, H.D., and Harlan, J.M. (1986) J. Immunol. 136,4548-4553.

3. Collins, T.L., Lapierre, L.A., Fiers, W., Strominger, J.L., and Pober, J.S. (1986) Proc. Natl. Acad. Sci. USA 83,466-479.

4. Nawroth, P.P., Bank, I., Handley, D., Cassimeris, J., Chess, L., and Stern, D.J. (1987) Exp. Med. 163,1363-1379.

5. Nawroth, P.P. and Stern, D.J. (1986) J. Exp. Med. 163,740-745.

6. Pober, J.S., Gimbrone, M.A., Lapierre, L.A., Mendrick, D.L., Fiers, W., Rothelein, R., and Springer, T.A. (1986) J. Immunol. 137,1893-1905.

7. Gamble, J.R., Harlan, J.M. Klebanoff, S.J. and Vadas, M.A. (1985) Proc. Natl. Acad. Sci. USA 82,8667-8680.

8. Jaffe, E.A. (1984) in, Biology of Endothelial Cell (Jaffe, E.A. editor) Martines Nijhoff, The Hague pp. 1-29.

9. Jonas, E., Sargent, T.D., and David, I.B. (1985) Proc. Natl. Acad. Sci. USA 82,5413-5417.

10. Chirgwin, J.M., Przybyla, A.E., MacDonald, R.J. and Rutter, W.J. (1979) Biochem 18,5294-5299.

11. Matsushima, K, Morishita, K., Yoshimura, T., Lavu, S., Kobayashi, Y., Lew, W., Appella, E., Kung, H.F., Leonard, F.J., and Oppenheim, J.J. (1988) J. Exp. Med. 167,1883-1893.

12. Harvath, L., Falk, W., and Leonard, E.J. (1980) J. Immunol. Meth. 37,39-45.

13. Bevilacqua, M.P., Pober, J.S., Majeau, G.R., Fiers, W., Cotran, R.S., and Gimbrone, M.A. Proc. Natl. Acad. Sci. USA 83,4533-4537.

14. Kawakani, M., Ishibashi, S., Ogawa, H., Murose, T., Takaku, F., and Shibata, S. (1986) Biochem. Biophys. Res. Commun. 141, 482-487.

15. Camussi, G., Bussolino, F., Salvidio, G., and Baglioni, C. (1987) J. Exp. Med. 166,1390-1403. 